\title{
The importance of conscientiousness in the telemarketing industry
}

\author{
B. Gaertner, L. Lambson, M. Mbuyu and E. Botha* \\ All authors: Marketing Section, School of Mánagement Studies, \\ University of Cape Town, Tel: 0216504052 \\ *To whom all correspondence should be addressed \\ elsamari.botha@uct.ac.za
}

\begin{abstract}
Researchers have long pondered the personality type-performance relationship. However, in the sales industry and especially in telemarketing, findings have been contradictory with regards to which personality trait best contributes to performance. The telemarketing industry is a rapidly growing industry, but is typically marred with high staff turnover and low levels of performance. An improved understanding of the factors that contribute towards performance in this industry is a key mandate of management. Personality-type has been shown to be a key driver of performance in the sales industry. However, it is unclear whether the personality types touted in typical sales positions (for example extroversion) are suited for the telemarketing environment. South Africa is one of the top emerging call centre locations in the world and as such the purpose of this study was to determine which personality type best contributes towards performance in the South African telemarketing industry. A census was conducted on telesales personnel in a large telemarketing organisation and the five-factor model was used to test employees' personality types. Contrary to current research, which suggests that extrayersion is the five-factor trait best suited to salespeople, this study found that conscientiousness was the only personality trait that influenced sales performance in the call centre context.
\end{abstract}

\section{Introduction}

With the increasingly important role that call centres are playing in business today, coupled with the steep rise in the number of call centres in South Africa, a better understanding of what drives sales performance in the telesales environment is a key focus of managers. Recently, this industry has experienced an annual growth of $10 \%$ (Holman, Batt \& Holtgrewe, 2007). This is said to be influenced by the major improvements in technology (Stone \& Whyman, 1992) and consumers' growing need for 24 hour service (Rose \& Wright, 2005).

One factor that has been shown to affect sales performance in general, is the personality traits of salespeople. Researchers have long pondered the relationship between personality and sales performance (Barrick, Stewart \& Piotrowski, 2002; Furnham \& Fudge, 2008; Warr, Bartram \& Martin, 2005) and it was found that certain personality traits appear to be associated with sales performance success (Barrick \& Mount, 1991; Lamont \& Lundstrom, 1977). In general, traits like extroversion and conscientiousness have been favoured in salespeople (Barrick, Mount \& Judge, 2001). However, it is not elear whether the same personality traits should be favoured in telesales personnel, who function in a completely different sales environment compared to those salespeople who interact with clients face-to-face (Tidmarch cited in Gordi, 2006). The nature of sales within the telemarketing industry is consequently different from the traditional sales context (Mount, Barrick \& Stewart, 1998) where most personality type-performance research has taken place. In the call centre environment, performance has been linked to factors such as the quality of call handling, number of calls handled, average handling time for calls handled, number of sales generated per month, revenue generated on average per call and conduct (Adendorff, 2011),

However, the personality-performance relationship in the telesales environment is unclear (Sawyerr, Srinivas, \& Wang, 2009).

Researchers studying the personality type-performance relationship in this industry often have contradictory findings: Sawyerr et al. (2009) found openness to experience to have the strongest relationship and Skyrme, Wilkinson, Abraham \& Morrison (2005) identified conscientiousness, agreeableness and emotional stability to be among the strongest links to performance. This paper therefore investigates this relationship in the telesales 
industry of South Africa by using the five-factor model of personality types. The majority of research investigating the relationship between personality and performance has made use of the five-factor model (FFM) (Barrick et al., 2001) and the scale has also been successfully applied to the telemarketing industry (Sawyerr et al, 2009; Skyrme et al., 2005). The following research question was developed for this study:

\section{"Which personality traits of the five-factor model impact the performance of salespeople in the telemarketing industry of South Africa?"}

The five dimensions of the model consist of extroversion, agreeableness, conscientiousness, emotional stability (vs. neuroticism) and openness to experience (Sawyerr et al., 2009; Witt, 2002). Consequently, the following objectives for this study were formulated:

- To determine which of the FFM personality traits are significantly related to the performance of salespeople in the telemarketing industry of South Africa.

- To determine which of the five dimensions of the FFM, when considered together, have the greatest influence on the performance of salespeople in the telemarketing industry of South Africa.

The contribution of this study is threefold. First, the discrepancies (and often contradictory findings) in previous research will be addressed by looking at the contribution of each personality type to telesales performance. Second, this relationship will be investigated in the South African context. To the knowledge of the authors, no previous research has looked at this relationship in the South African context even as call centres and telemarketing initiatives are burgeoning across the country - South Africa was recently listed among the top three call centre locations in the world (Winde, 2011). Lastly, the telemarketing industry also faces high staff turnover rates (Sawyerr et al., 2009), which negatively impact the effectiveness of an organisation (Price, 1995). In fact, South Africa has one of the highest turnover rates in this industry, contributing to more than $60 \%$ of total costs to call centres in 2007 (Holman et al., 2007). This could be another indication that traditional thinking, with regards to which personality types should be employed in telemarketing, may be faulty. By selecting effective personnel who are likely to persevere (Sawyerr et al., 2009) and perform, the organisation's bottom line should improve (Vinchur, Schippmann, Switzer \& Roth, 1998).

This paper is structured as follows: First a literature review investigates the personality type-performance relationship by looking at sales performance and then delineating the five dimensions of personality according to the five-factor model of personality types. The five hypotheses that form the focus of this study are presented in the literature review. This is followed by a discussion of the methodology and then the results of the study are presented. Thereafter, these results are discussed in greater depth and a discussion of the limitations of the study and future research follows.

\section{Personality and performance in the telemarketing industry}

High staff turnover experienced in call centres, is believed to be linked to the nature and environment of the work these employees are subjected to (Sawyerr et al., 2009; Holman et $a l ., 2007$ ). Identifying potential employees who are likely to perform and persist (Sawyerr et al., 2009) is said to improve organisational productivity (Vinchur et al., 1998). Recently, research has focused more on formulating methods to predict potential salespeople's performance (Hakstian, Scratchley, MacLeod, Tweed \& Siddarth, 1997). Psychological testing is one of the many assessments used to select sales people (Cooper \& Robertson, 1995; Fisher, Katz, Miller \& Thatcher, 2003) and entails cognitive ability tests, assessing general ability skills, and/or personality tests. These in turn determine whether the individual will behave in the manner required by the organisations (Cooper $\&$ Robertson, 1995). Since call centre work is believed to be generally low skilled (Holman et al., 2007) less focus needs to be given to general ability skills and more value placed on personality testing.

However, the use of personality tests in employee selection has been a heavily debated subject in South Africa (Fisher, Katz, Miller \& Thatcher, 2003). Some South African practitioners believe that personality tests are not suited for non-Western individuals (Dan, 1998) whereas others claim that there are personality dimensions that are consistent worldwide regardless of culture (Lucas, Diener, Grob, Suh $\&$ Shao, 2000). In addition, self-report personality testing is said to be less valid due to the possibility of faking (Chamorro-Premuzic \& Furnham, 2010; Cooper \& Robertson, 1995). Nevertheless, personality testing is still a popular and empirically validated method used in the selection process (Barrick \& Mount, 1991; Skyrme et al., 2005).

Substantial research also points to a relationship between personality and performance (Barrick et al., 2001; Barrick et al., 2002; Sawyerr et al, 2009; Skyrme et al., 2005) and this provides another justification for the use of personality testing in appointing call centre staff. This literature review section focuses on the two primary constructs of this study, namely personality and performance of salespeople.

\section{Sales performance}

Empirical research on sales performance dates back to the early 1900 's (Oschrin, 1918). Consequently, the construct has been defined in various ways (Singh \& Koshy, 2010) with numerous researchers describing it as the salesperson's outcomes and his/her behaviour (Anderson \& Oliver, 1987; Challagalla \& Shervani, 1996; Cravens, Ingram, LaForge \& Young, 1993). Outcomes include facets such as: sales units, market share and revenue and behaviours refer to skills at 
selling, customer orientation and selling activities (Anderson \& Oliver, 1987).

Many studies have used both subjective (e.g. ratings) and objective (e.g. sales) methods to measure the performance of salespeople (Barrick et al, 2001; Judge, Thoresen, Bono \& Patton, 2001; Singh \& Koshy, 2010). Subjective measures are generally questionnaires completed by supervisors, peers or the individuals themselves (self-rating) (Sawyerr et al., 2009; Skyrme et al., 2005) whereas objective measures are "direct measures of countable behaviours or outcomes" (Bommer, Johnson, Rich, Podsakoff \& Mackenzie, 1995:588) which typically include sales volume, productivity or revenue (Barrick et al., 2001). Other objective performance measures have been based on sales per hour, talk time, adjusted sign-on time and wrap time (Hakstian et al., 1997), amount of calls completed in a certain time frame (Fellows \& Mawhinney, 1997), number of successes divided by sum of successes and failures (Skryme et al., 2005), thoroughness of agent in providing information and swiftness and skill of responding to customer problems (Sawyerr et al., 2009). Other authors argue that customer service plays a major role in their job description and that dealing with customer queries takes up a large portion of their work (Conte \& Gintoft, 2005). This seems to be especially true in the telemarketing industry, where many call centre agents are required to provide customer service as well as making sales (Arens, Weigold \& Arens, 2009; Frei \& McDaniel, 1998; Gordi, 2006; Sawyerr et al. 2009). Consequently, when considering the performance of salespeople in the telemarketing industry, both sales and service aspects of the job need to be accounted for.

\section{The personality-performance relationship}

Personality traits have been described as an individual's innermost, unwavering personal makeup, which influence his or her behaviour and thoughts and feelings in various given situations (Chamorro-Premuzic \& Furnham, 2010; Pervin, Cervone \& John, 2005). Therefore personality is said to be helpful in predicting work-related behaviour (Chamorro-Premuzic \& Furnham, 2010; Pervin et al., 2005).

Since the convergence of agreement on five broad basic dimensions of personality in the 1980 s (Furnham \& Fudge, 2008; McCrae \& Costa, 2003; Pervin et al., 2005), there has been accumulating evidence indicating personality as a useful predictor of various criteria (Hough, Eaton, Dunnette, Kamp, \& McCloy, 1990) and in particular job performance (Judge \& Erez, 2007). The five-factor model (FFM) is the most widely used personality classification system and scale (Cooper \& Robertson, 1995).

\section{The five-factor model of personality}

The FFM has been most extensively used to study the personality-performance relationship in various occupations, including sales, where significant relationships have been found (Barrick et al., 2001; Conte \& Gintoft, 2005; Sawyerr et al., 2009). Service performance has also been found to be strongly related to personality traits of the FFM (Conte \& Gintoft, 2005; Sawyerr et al., 2009).

There is still some dispute as to the names and content of the five factors (Barrick et al., 2001; Pervin et al., 2005) but typically they have been labelled as extroversion (Factor I), agreeableness (Factor II), conscientiousness (Factor III), emotional stability/neuroticism (Factor IV), and openness to experience (Factor V) (Chamorro-Premuzic \& Furnham, 2010; Witt, 2002).

\section{Extroversion (Factor l)}

Factor I defines individuals high in extroversion as talkative, energetic, enthusiastic, assertive and outgoing and those who are low in extroversion (i.e. introverted) as reserved, quiet and shy (John \& Srivastava, 1999; John, Naumann \& Soto, 2008).

Numerous researchers have found a significant extroversion-performance relationship in sales (Barrick \& Mount, 1991; Hurtz \& Donovan, 2000; Witt, 2002; Conte \& Gintoft, 2005). However, it has been proposed that the strength of this relationship is very much dependent on the type of sales job, considering the fact that some studies have failed to identify any significant relationship (Furnham \& Fudge, 2008). For example, sales contexts where face-toface contact between salespeople and clients are required could benefit sales personnel with extroverted personalities. Consequently, extroversion has been shown to be useful for occupations that entail a considerable amount of interpersonal interaction (Barrick \& Mount, 1991; Witt, 2002). Considering that the call centre environment is technologically driven and allows for minimal teamwork with colleagues as well as no face-to-face interaction with clients (Sawyerr et al., 2009), little face-to-face interpersonal interaction is involved, thereby suggesting that extroversion may be less relevant for salespeople in call centres (Sawyerr et al, 2009; Witt, 2002).

Literature that has studied the link between extroversion and sales performance has frequently found a positive relationship (Barrick \& Mount, 1991; Barrick et al., 2001; Conte \& Gintoft, 2005). Some studies have also shown a strong, significant relationship between this trait and service performance (Conte \& Gintoft, 2005; Liao \& Chuang, 2004). However, Stewart and Carson (1995) found the relationship to be negative in some service contexts. Therefore there is uncertainty as to whether extroversion would be positively related to sales performance in the telesales industry, and the following hypothesis was formulated:

H1: Extroversion is positively related to performance in the South African telemarketing industry.

\section{Agreeableness (Factor II)}


Individuals high in agreeableness are helpful, forgiving, trusting, kind and cooperative as well as caring, flexible and soft-hearted (Barrick \& Mount, 1991). Those who are low in agreeableness are fault-finding, quarrelsome, cold and unfriendly (John \& Srivastava, 1999).

As with extroversion, the agreeableness-sales performance relationship has been relatively inconsistent across analyses: Some studies find a positive relationship (Mount et al., 1998; Skyrme et al., 2005), others a negative relationship (Furnham \& Fudge, 2008) and some no significant relationship at all (Sawyerr et al., 2009). Sawyerr et al. (2009) are of the opinion that traits associated with agreeableness are well suited for a job in telemarketing because call centre agents often need to deal with difficult customers. However, agreeable individuals are also believed to be more cooperative than competitive (Barrick et al, 2002). Thus this characteristic is more useful for those occupations that demand a significant amount of teamwork (Mount et al, 1998). In the sales environment, and telesales in particular, there is little or no teamwork involved (Sawyerr et al., 2009). Instead, competition with others is encouraged and success is measured on an individual performance basis (Furnham \& Fudge, 2008). It is therefore uncertain whether agreeableness will positively influence performance in the telesales industry, and the following hypothesis was formulated:

H2: There is a positive relationship between salespeople's agreeableness and their performance in the South African telemarketing industry.

\section{Conscientiousness (Factor III)}

Individuals who are high in conscientiousness are thorough, reliable, organized, efficient and deliberate, while those who are low in conscientiousness are careless, disorderly, irresponsible and forgetful (John \& Srivastava, 1999). Conscientious people have also been characterized as persevering, hardworking (Mount et al., 1998) and driven (Skyrme et al., 2005).

The results of the meta-analysis conducted by Barrick and Mount (1991) showed conscientiousness as the only dimension that was positively related across all occupational groups consistently (including sales). Subsequent studies obtained the same finding (Furnham \& Fudge, 2008; Skyrme et al., 2005; Vinchur et al., 1998). John and Srivastava (1999) argued that this result might be owed to conscientious people being less impulsive and this boosting their performance in the workplace. It is particularly useful for salespeople to be achievement-orientated and to persevere as they need to tolerate large amounts of unsuccessful sales relative to successful sales (Vinchur et al., 1998). Therefore it is understandable why conscientious salespeople are more likely to be better performers.

Furthermore, traits such as dutifulness and perfectionism are believed to be well suited for persons working in a call centre environment (Bames, 2001), especially in the customer service work (Sawyerr et al, 2009). This is evident in studies that have found conscientiousness to have the strongest relationship with service performance (Liao \& Chuang, 2004). Based on these arguments, it is expected that salespeople in the telemarketing industry will perform significantly better if they are conscientious, and the following hypothesis was formulated:

H3: Salespeople's conscientiousness is positively related to their performance in the South African telemarketing industry.

\section{Neuroticism (Factor IV)}

Individuals who are emotionally stable are calm and able to tolerate stress better compared to those who are neurotic, where neurotic is defined as despondent, tense, worrying, moody and nervous (John et al., 2008). Emotionally stable people are also considered to be more secure in themselves (Mount et al., 1998), whereas neurotic individuals are more depressed and self-conscious (Barrick \& Mount, 1991).

Researchers have found the relationship between performance and emotional stability to be positive (Skyrme et al., 2005). This is because being calm, stable and able to tolerate stress should allow the worker to interact better with customers and colleagues thereby aiding them to complete their job tasks (Barrick et al., 2001). Nonetheless, it has been suggested that neurotic people may actually do well in sales because the act of making a sale could boost their confidence by providing motivation (Furnham \& Fudge, 2008).

Mount et al. (1998) on the other hand found that this trait is particularly predictive of performance in jobs that entail substantial interpersonal interaction, which has been supported by similar findings in the customer service context (Frei \& McDaniel, 1998). However, as stated earlier, work in the telemarketing industry does not require much interpersonal interaction. Therefore, it is still unclear whether emotional stability would be positively related to sales performance in the telesales industry and the following hypothesis was formulated:

H4: Neuroticism amongst salespeople is negatively related to their performance in the South African telemarketing industry.

\section{Openness to experience (Factor V)}

Individuals high in openness to experience are original, curious, insightful, imaginative, inventive, artistic and have wide interests compared to those who are not open to experience, defined as simple and commonplace (John et al, 2008).

McCrae (cited in Griffin \& Hesketh, 2004) observed that among the five factors, openness to experience has received 
the least attention (therefore also the least understood) and is the most controversial dimension of the FFM. Across occupational groups and performance criteria it was continuously found to have weak relationships with performance (Barrick et al., 2001; Liao \& Chuang, 2004). However, more recently, researchers Furnham and Fudge (2008) found a strong positive correlation between openness to experience and sales performance. They explain that individuals who are creative and imaginative can think of different ways to sell to different clients. In a study on salespeople in a call centre, openness to experience had a strong negative relationship with performance (Sawyerr et al., 2009). This result was explained by the fact that the work these salespeople do is heavily supervised and the conversations with the customers are scripted, thereby restricting an 'open' person. This and the fact that the work is very repetitive, leaves little room for autonomy (Bain \& Taylor cited in Sawyerr et al., 2009). The openness to experience-sales performance relationship is therefore uncertain in the telesales industry, and the following hypothesis was created:

H5: Openness to experience is positively related to performance in the South African telemarketing industry.

While the relationship between each personality trait and sales performance is first established through $\mathrm{H} 1$ to $\mathrm{H} 5$, it was also necessary to ascertain which of the five dimensions, when considered together, had the greatest influence on sales performance. Objective 1 is addressed through hypotheses 1 through 5, objective 2 , however, considers each of the five dimensions together. Consequently, the second part of the analysis for this study questioned which of the five factors, when considered together, had the greatest influence on sales performance in the telesales industry. The following section addresses the methodology used to test these hypotheses, followed by the results.

\section{Methodology}

This study employed a descriptive research design (Malhotra, 2010), with quantitative data analysis and findings, which may be used as input into the decisionmaking process of personnel recruitment and selection. The target population consisted of 250 call centre agents in an international telemarketing organisation based in Cape Town. To increase the realised sample size of the selfcompletion survey used, a census was appropriate. A survey is often deemed most appropriate in the measurement of personality type (John \& Srivastava, 1999). By using a census, random sampling error was eliminated and the sample was a good reflection of the population. Furthermore, a census better accounts for the possible high variance in personality traits of the respondents (Malhotra, 2010).

Various approaches and measurement instruments have been suggested for the measurement of the five dimensions contained in the Five Factor Model. This study used the Big
Five Inventory (BFI), which is perceived as one of the better FFM instruments available due to its emphasis on clarification and the favourability in time constrained environments (John \& Srivastava, 1990). The BFI is a wellestablished and widely used measurement instrument of these traits (John \& Srivastava, 1999; Gosling, Rentfrow \& Swann, 2003) and has proven to be reliable with Cronbach Alpha values ranging from between 0.75 and 0.90 and testretest reliability of around 0.85 (John \& Srivastava, 1999; Benet-Martinez \& John, 1998). This scale has also been used successfully in various South African studies (see for example Schmitt \& Shackelford, 2008). Therefore the BFI was used in this study's self-administrated survey. Each BFI personality construct, as well as sales performance, was measured using 5-point Likert scales.

Based on the suggestion of Sujan, Weitz and Kumar (1994), a self-rating scale was used to measure employees' performance. Although some studies claim that selfreporting measures for performance are susceptible to social desirability bias (Mechinda \& Patterson, 2011), others have shown that upward bias may exist in the mean values but not in correlations with other constructs. Furthermore, evidence exists which suggests that when respondents feel their responses will remain anonymous; they have less motivation to present themselves in a socially desirable manner (Schneider, Bowen, Holcombe \& Ehrhart cited in Mechinda \& Patterson, 2011). Also, self-reporting instruments for measuring performance have been used by various researchers in the sales industry (Silver, Dweyer \& Alford, 2006; Wang \& Netemeyer, 2004; Sharma, Rich \& Levy, 2004); even in the context of telemarketing (Malhotra \& Mukherjee, 2004). Although a single item for measuring this construct is undesirable, it has been used by various researchers (Rotundo \& Sackett, 2002; Witt \& Ferris, 2003; Ferris, Witt \& Hochwarter, 2001). Evidence of its use on call centre agents also exists ( Nel \& De Villiers, 2004). This, along with the widespread use of single item selfrating measures of performance allows this measure to be acceptable in this study.

The final sample consisted of a total of 107 usable questionnaires, representing a $43 \%$ response rate, which is similar to recent studies in this industry, which have obtained a response rate of $37 \%$ (Sawyerr et al., 2009).

\section{Results}

This section aims to address the results with regards to the overall research question stated in the introduction. After the reliability and validity of the measurement instrument is discussed, relevant descriptive statistics are provided and the findings with regards to objective 1 and objective 2 are analysed.

Table 1 summarizes the internal consistency reliability measures, measured using Cronbach's Alpha. For each construct a value greater than 0,6 is generally believed to be acceptable (Malhotra, 2010; Setbon \& Roaude, 2010) and all constructs were consequently found to be reliable. 
Table 1: Internal consistency reliability of scales

\begin{tabular}{l|c|c|c}
\hline Variable & n & $\begin{array}{c}\text { Cronbach's } \\
\text { Alpha }\end{array}$ & $\begin{array}{c}\text { Number } \\
\text { of items }\end{array}$ \\
\hline Extroversion & 95 & 0,76 & 8 \\
\hline Agreeableness & 102 & 0,75 & 9 \\
\hline Conscientiousness & 100 & 0,72 & 9 \\
\hline Neuroticism & 102 & 0,78 & 8 \\
\hline Openness to experience & 100 & 0,64 & 10 \\
\hline
\end{tabular}

Given that all five personality constructs' scales were found to be reliable, based on the Cronbach Alpha without removing any items, and the fact that the BFI has been found to be valid, based on construct validity (BenetMartinez \& John, 1998; De Young, 2006; Gosling et al, 2003; John \& Srivastava, 1991), no items were removed.

\section{Sample demographics}

The majority $(59.2 \%)$ of call centre agents were between the ages of $25-34,23.3 \%$ were between the age of $19-24,10.7 \%$ were between 35-44 and the remainder of the sample indicated that they were older than 44 . The majority of respondents were female $(71.6 \%)$ and a relatively representative sample was drawn when considering "years of experience" ( $28.8 \%$ had less than 1 years' experience, $39.4 \%$ between $1-3$ years, and $31.7 \%$ had 4 or more years' experience).

Table 2 shows the mean and standard deviation of performance and each of the personality constructs: extroversion, agreeableness, conscientiousness, neuroticism and openness to experience. The scale values for personality constructs, as well as for performance, ranged from 1 ("strongly disagree") to 5 ("strongly agree").

Table 2: Means and standard deviations of personality constructs and performance $(n=107)$

\begin{tabular}{l|l|l|l}
\hline Construct & Variable & $\begin{array}{l}\text { Mean } \\
(\boldsymbol{M})\end{array}$ & $\begin{array}{l}\text { Standard } \\
\text { deviation } \\
(\boldsymbol{S D})\end{array}$ \\
\hline \multirow{2}{*}{$\begin{array}{l}\text { Five-Factor } \\
\text { Model }\end{array}$} & Extroversion & 3,55 & 0,62 \\
\cline { 2 - 4 } & Agreeableness & 4,03 & 0,50 \\
\cline { 2 - 4 } & Conscientiousness & 3,87 & 0,48 \\
\hline
\end{tabular}

\begin{tabular}{|c|c|c|c|}
\hline & Neuroticism & 2,52 & 0,62 \\
\hline & $\begin{array}{ll}\text { Openness } & \text { to } \\
\text { experience } & \end{array}$ & 3,65 & 0,46 \\
\hline Performance & . & 3,74 & 0,67 \\
\hline
\end{tabular}

Extroversion had a mean of $3,55(S D=0,62)$, which indicated that respondents agreed with the items in this construct. Similar results were seen with openness to experience $(M=3,65$ and $S D=0,46)$. Agreeableness displayed slightly different results with a mean of 4,03 (SD $=0,50$ ) indicating that the average respondent moderately agreed with the items within the construct. The results obtained for conscientiousness were similar $(M=3,87$ and $S D=0,48$ ). The only construct, with which the average respondent moderately disagreed with, was neuroticism ( $M$ $=2,52$ and $S D=0,62$ ) i.e. this construct displayed responses between moderately disagree and neutral. The final construct, performance, had a mean of $3,74(S D=0,67)$ indicating that respondents and their supervisors found the average call centre agent to have average to high overall performance. Scale values for performance ranged from 1 ("low overall performance") to 5 ("high overall performance").

Now we will discuss the findings with regards to each objective. Bivariate correlation and regression analysis were used to investigate the relationship between the five personality traits and performance.

\section{Objective 1: The relationship between each factor and performance}

Objective 1 attempted to determine the relationship between each of the five factors and performance, where H1 - H5 were used to test these relationships. Hypotheses 1 to 5 tested the relationship between each of the five factors and performance. Since all the main variables (extroversion, agreeableness, conscientiousness, neuroticism, openness to experience and performance) were measured on an interval scale and found to meet the normality assumption, Pearson's correlations coefficient was the appropriate parametric test to investigate the correlations between sales performance and the personality traits. Table 3 reports the findings from the bivariate correlation test.

Table 3: Bivariate correlation matrix to test hypotheses 1 to 5

\begin{tabular}{|c|c|c|c|c|c|c|}
\hline & $\begin{array}{l}\text { Extroversion } \\
\text { (H1) }\end{array}$ & $\begin{array}{l}\text { Agreeableness } \\
\text { (H2) }\end{array}$ & $\begin{array}{l}\text { Conscientiousness } \\
\text { H3) }\end{array}$ & $\begin{array}{l}\text { Neuroticism } \\
\text { (H4) }\end{array}$ & $\begin{array}{l}\text { Openness } \\
\text { (H5) }\end{array}$ & Performance \\
\hline Extroversion & 1 & & & & & \\
\hline Agreeableness & $-0,02$ & 1 & & & & \\
\hline Conscientious-ness & 0,05 & $0,50^{*}$ & 1 & & & \\
\hline Neuroticism & $-0,27 *$ & $-0,41 *$ & $-0,58 *$ & 1 & & \\
\hline $\begin{array}{ll}\text { Openness } & \text { to } \\
\text { experience } & \\
\end{array}$ & $0,32 *$ & 0,19 & $0,25^{*}$ & $-0,17$ & 1 & \\
\hline Performance & $0,22^{*}$ & 0,18 & $0,36^{*}$ & $-0,20 *$ & 0,22 * & 1 \\
\hline
\end{tabular}

Notes: ${ }^{*}$ Correlations are significant at the $5 \%$ level $(\mathrm{p}<0,05)$

Hypothesis 1 concerned the positive relationship between extroversion and performance; $\mathrm{H}_{2}$ the positive relationship between agreeableness and performance; $\mathrm{H} 3$ the positive relationship between conscientiousness and performance; 
H4 the negative relationship between neuroticism and performance; and $\mathrm{H} 5$ the positive relationship between openness to experience and performance. Four of the five null hypotheses were rejected (at a 5\% level of significance), where only agreeableness was not found to be significantly related to performance. Neuroticism indeed had a negative relationship with performance, and conscientiousness seemed to have the greatest correlation to performance. However, it was still unclear which of these five factors would have the greatest influence on performance, when considered together. Consequently, objective 2 was tested using regression analysis.

\section{Objective 2: Which factor had the greatest influence on performance?}

From the correlation matrix, it appears that extroversion, conscientiousness, neuroticism and openness are related to performance, where neuroticism was negatively correlated to performance. However, it would be erroneous to investigate these relationships in isolation. The relationships found were further examined with multiple regression in order to identify whether any of these may be spurious. The following regression model was formulated according to theory:

where $\beta_{1}$, and $\beta_{4}$ were hypothesised to equal zero, $\beta_{2}$ and $\beta_{3}$ were hypothesised to be positive and $\beta_{5}$ hypothesised to be negative. The results of the regression, as depicted in table 4 , suggest the following estimated equation:

\section{performance $=0.05+0.22$ (extroversion) + 0.03 (agreeableness) +0.55 (conscientiousness) + 0.22 (neuroticism) +0.12 (openness to experience)}

The model was found to be significant ( F-statistics $=4,38$; $\mathrm{p}$ value $=0,00)$. The coefficient of multiple determination $\left(\mathrm{R}^{2}\right.$ adjusted) was 0,14 for the fitted model. This means that only $14 \%$ of total variation in performance is explained by the regression model, only $1 \%$ more than the amount explained by conscientiousness $\left(r^{2}=0,13\right)$. This suggests that the addition of the other personality variables do not contribute much to explaining the variation in performance. Table 4 shows which specific partial correlation coefficients are significantly different from zero. Only conscientiousness's coefficient $(b=0,55)$ was found to be different from zero at the $5 \%$ level of significance $(\mathrm{p}$-value $=0,00)$.

Table 4: Multiple regression results: parameter estimates, standard errors, standardised betas, associated p-value and VIF statistics $(n=104)$

\begin{tabular}{l|c|c|c|c}
\hline & $\begin{array}{c}\text { Unstandardized } \\
\text { coefficients }\end{array}$ & Std. Error & $\begin{array}{c}\text { Standardized } \\
\text { coefficients }\end{array}$ & Collinearity \\
statistics
\end{tabular}

Notes: Dependent variable: performance $(\mathrm{Y}) ; \mathrm{VIF}=$ variation inflation factor

The results of the multiple regression suggest that it is spurious to consider each individual relationship with performance, but all five factors need to be considered at the same time. When the five factors were considered together, conscientiousness was the only significant contributing factor to performance in the telemarketing industry.

In order to evaluate the efficacy of the regression model above, the residuals were further investigated to determine whether the underlying assumptions of multiple regression were satisfied. The assumptions of a normally distributed error term were visually investigated by analysing the normal probability plot. The observed residuals resided close to the 45-degree line indicating a normally distributed error term. This was confirmed by the Kolmogorov-Smirnov (K-S) one-sample test, whereby $\mathrm{H}_{0}$ of a normally distributed error term was not rejected at the $5 \%$ level of significance ( $\mathrm{p}$-value $=0,20)$. The assumption of constant variance of the error term appears to be violated as there seems to be a relationship between the standardized residuals and standardized predicted values. However, the Durbin Watson test proved that the error terms were independent of each other since the test statistic $(d=1,86)$ was greater than the upper limit $\left(d_{t s}=1,78\right)$. Therefore, there seems to be no major violations and the data was deemed robust enough for multiple regression. As the model was found to be 
appropriate, the following section takes a closer look at the implications of these findings.

\section{Discussion}

The purpose of this study was to determine the relationships between personality factors, as modelled by the FFM, and the performance of salespeople in the telemarketing industry of South Africa. Most previous studies have focused on the personality-performance relationship of personnel in sales and service occupations that entail face-to-face interaction (Barrick \& Mount, 1991; Barrick et al., 2002; Furnham \& Fudge, 2008; Vinchur et al., 1998). Furthermore, the studies that do exist within the telemarketing industry appear to be conducted in the United States of America (Sawyerr et al., 2009; Skyrme et al., 2005). This study contributes to the scarce literature on the personality traits of salespeople in telemarketing, and in particular provides more insight on this topic within in the context of South Africa. The findings of this study should aid organisations that make use of telemarketing to select salespeople whose personalities are more suited for the job, thereby reducing the staff turnover rate, which is especially common in the industry (Sawyerr et al., 2009). Furthermore, productivity will be improved (Price, 1995) and consequently the bottom line (Vinchur et al., 1998).

The results revealed that conscientiousness was the only personality trait that was related to performance of salespeople in the South African telemarketing industry. This is contrary to popular belief, as extroversion is often seen as the main reason for sales success. While some authors have hinted that both extroversion and conscientiousness are important indicators of sales performance (Barrick et al., 2001; Vinchur et al., 1998), this study shows that conscientiousness alone is a key indicator of performance in the telemarketing industry. This means that sales staff who are thorough, reliable, organized, efficient, deliberate, (John \& Srivastava, 1999), persevering, hardworking (Mount et al., 1998) and driven (Skyrme et al., 2005) will have the greatest likelihood of success in the telemarketing industry in South Africa.

Various aspects of this positive conscientiousnessperformance relationship are believed to contribute to good performance in the sales industry in general. For example, John and Srivastava (1990) believe that the impulsive nature of conscientious individuals is valuable in this industry and traits like dutifulness and perfectionism are well suited for people working in call centres (Barnes, 2001). Moreover, characteristics like perseverance and achievement orientation are useful when having to deal with large amounts of unsuccessful sales (Vinchur et al., 1999). Recruiters generally focus on finding people who are extroverted (Sawyerr et al., 2009), but this study suggests that instead the focus should be on finding conscientious employees.

While the value of extroverted sales personnel should not be underestimated, this study suggests, like Mount et al. (1998) that the relationship between personality and performance is largely moderated by the nature of work. Extroversion is considered to be valuable for those jobs requiring extensive interpersonal interaction (Barrick \& Mount, 1991; Witt, 2002) whereas the work done as a call centre agent is highly technologically driven, allowing for minimal teamwork and no face-to-face interaction with customers (Sawyerr et al., 2009).

The findings with regards to the relationships between performance and the constructs of agreeableness, neuroticism and openness to experience are justifiable. Firstly, the absence of an agreeableness-performance relationship can be explained by the fact that agreeable individuals possess both valuable and burdening qualities for the type of work done in call centres. For instance, agreeable people are believed to be flexible, courteous and able to tolerate difficult customers (Sawyerr et al., 2009), however, qualities such as being cooperative rather than competitive are less useful in a competitive environment such as sales (Furnham \& Fudge, 2008). In addition to this, the soft-hearted nature of agreeable people may actually make dealing with failure of unsuccessful sales difficult (Furnham \& Fudge, 2008). Secondly, neurotic individuals are less likely to be able to handle stress, thereby making them less capable of interacting with customers (Barrick et al., 2001). Furthermore, given that this trait has been mostly found to be related to the performance of jobs entailing considerable interpersonal interaction (Frei \& McDaniel, 1998) and call centre work does not involve much of this, no relationship is generally expected (Sawyerr, et al., 2009). Finally - the most controversial - openness to experienceperformance relationship has been found to be insignificant by various previous studies (Barrick et al., 2001; Liao \& Chuang, 2004). It is deemed useful for sales jobs where being creative and imaginative can help when selling to different types of customers (Furnham \& Fudge, 2008). However, in call centre work, everything is highly scripted and monitored indicating that this trait may not be so helpful (Bain \& Tailor, 1999 in Sawyerr et al., 2009).

Employment in call centres has expanded internationally (Deery, Iverson \& Walsh, 2002). In light of this expansion, Brenner (2006) believes that call centres indicate a potentially beneficial employment opportunity for South Africa. This may be explained by the following: most South Africans speak reasonably good English, requiring little linguistic training (Kjellerup, 2001), the country's telecommunications technology is said to be advanced, allowing for good network comnections with other countries (Jons cited in Gordi, 2006) and its similarity in time zone to European countries. All these factors give South African call centres a competitive advantage over other locations (Petrie, 2004). South Africa should capitalize on future telemarketing expansion by making these businesses as profitable as possible. One way to increase the profitability of these call centres, this study suggests, is by employing conscientious telesales staff.

\section{Limitations and future research}


The first limitation of the study was associated with the selfrated performance measure. Skryme et al. (2005) argue that call centres typically use objective measures to measure their call centre agents' performance and these might be more appropriate in this context. However, this information is sensitive and confidential and not often available, as was the case in this study. Future researchers should try to use both objective and subjective measures of performance and compare the results.

One's personality at work might also be slightly different from one's personality in other social settings. Heller, Ferris, Brown \& Watson (2009:1055) explain that work personality, which is the "characteristic patterns of thoughts, feelings and behaviour at work", is different to home personality, which is the "characteristic patterns of thoughts, feelings and behaviour at home". Furthermore, the use of work personality can be used to increase the predictive validity of personality tests in predicting job performance (Bing, Whanger, Davison \& VanHook, 2004; Hunthausen, Truxillo, Bauer, \& Hammer, 2003).

\section{References}

Adendorff, D. (dadendorff@globaltelesales.co.za). (2011). Service performance. [Personal email, 22 July] to B. Gaertner (bmgaertner@gmail.com).

Anderson, E. \& Oliver, R.L. 1987. 'Perspectives on behavior-based versus outcome-based salesforce control systems', Journal of Marketing, 51(4): 76-88.

Arens, W.F., Weigold, M.F. \& Arens, C. 2009. Contemporary Advertising. $12^{\text {th }}$ Edition. New York, USA: McGraw-Hill Irwin.

Barnes, P.C. 2001. 'People problems in call centres', Management Services, 45(7): 30-1.

Barrick, M.R. \& Mount, M.K. 1991. 'The big five personality dimensions and job performance: a metaanalysis', Personnel Psychology, 44(1): 1- 27.

Barrick, M.R., Mount, M.K. \& Judge, T.A. 2001. Personality and performance at the beginning of the new millennium: what do we know and where do we go next?', Personality and Performance, 9(1/2): 9-30.

Barrick, M.R., Stewart, G.L. \& Piotrowski, M. 2002. Personality and job performance: test of the mediating effects of motivation among sales representatives', Journal of Applied Psychology, 87(1): 43-51.

Benet-Martinez, V. \& John, O.P. 1998. 'Los Cinco Grandes across cultures and ethnic groups: Multitrait-multimethod analyses of the Big Five in Spanish and English', Joumal of Personality and Social Psychology, 75(3): 729-750.

Bing, M.N., Whanger, J.C., Davison, K.H. \& VanHook, J.B. 2004. Incremental validity of the frame-of-reference effect in personality scale scores: a replication and extension', Journal of Applied Psychology, 89(1): 150-157.

Bommer, W.H., Johnson, J.L., Rich, G.A., Podsakoff, P.M. \& Mackenzie, S.B. 1995. 'On the interchangeability of objective and subjective measures of employee performance: a meta-analysis', Personnel Psychology, 48(3): 587-605.

Brenner, C. 2006. "South Africa on-call'; information technology and labour market restructuring in South African call centres', Regional Studies, 40(9): 1025-1040.

Challagalla, G.N. \& Shervani, T.A. 1996. 'Dimensions and types of supervisory control: effects on salesperson performance and satisfaction', Journal of Marketing, 60(1): 89-105.

Chamorro-Premuzic, T. \& Furnham, A. 2010. The Psychology of Personnel Selection. Cambridge, UK: Cambridge University Press.

Conte, J.M. \& Gintoft, J,N. 2005. 'Polychronicity, Big Five Personality Dimensions, and Sales Performance', Human Performance, 18(4):427-444.

Cooper, D. \& Robertson, T. 2000. In Fletcher, C. (Ed.) The psychology of personnel selection: a quality approach. London, UK: Thomson Learning.

Cravens, D.W., Ingram, T.N., LaForge, R.W. \& Young, C.E. 1993. 'Behavior-based and outcome-based salesforce control systems', Journal of Marketing, 57(4): 47-59.

Dan, R.H. 1998. 'Multicultural assessment of personality and psychopathology in the United States: still art, not yet science, and controversial', European Journal of Psychological Assessment, 14(1): 62-70.

Deery, S., Iverson, R. \& Walsh, J. 2002. 'Work relationships in telephone call centres: understanding emotional exhaustion and employee withdrawal, Journal of Management Studies, 39(4): 471-496.

Fellows, C. \& Mawhinney, T.C. 1997. 'Improving telemarketers' performance in the short-run using operant concepts', Journal of Business and Psychology, 11(4): 411424.

Ferris, G.L., Witt, L.A. \& Hochwarter, W.A. 2001. 'Interaction of social skill and general mental ability on job performance and salary', Journal of Applied Psychology, 86(6): 1075-1082.

Fisher, A., Katz, L., Miller, K. \& Thatcher, A. 2003. South Africa at work: applying psychology to organizations. Johannesburg, South Africa: Witwatersrand University Press.

Frel, R.L. \& McDaniel, M.A. 1998. 'Validity of customer service measures in personnel selection: A review of 
criterion and construct evidence', Human Performance, 11(1);1-27.

Furnham, A. \& Fudge, C. 2008. 'The five-factor model of personality and sales performance', Journal of Individual Differences, 29(1): 11-16.

Gordi, M.R. 2006. 'Job satisfaction of call centre representatives', Thesis, University of the Western Cape.

Gosling, S.D., Rentfrow, P.J. \& Swann, W.B. 2003. 'A very brief measure of the Big-Five personality domains', Journal of Research in Personality, 37; 504-528.

Griffin, B. \& Hesketh, B. 2004. "Why openness to experience is not a good predictor of job performance', International Journal of Selection and Assessment, 12(3): 243-251.

Hakstian, R.A., Scratchley, L.S., MacLeod, A.A., Tweed, R.G. \& Siddarth, S. 1997. 'Selection of telemarketing employees by standardized procedures', Psychology \& Marketing, 14(7): 703-726.

Heller, D., Ferris, D.L., Brown, D. \& Watson, D. 2009. 'The influence of work personality on job satisfaction: incremental validity and mediation effects ${ }^{\dagger}$, Journal of Personality, 77(4): 1051-1084.

Holman, D., Batt, R. \& Holtgrewe, U. 2007. The global call centre report international perspectives on management and employment. [Online].

URL:

http://www.ilr.cornell.edu/gloabalcallcentre.

Hunthausen, J.M., John, T.M., Donald, M., Bauer, T.N. \& Hammer, L.B. 2003. 'A field study of frame-of-reference effects on personality test validity ${ }^{3}$. Journal of Applied Psychology, 88(3): 545-551.

Hurtz, G.M. \& Donovan, J.J. 2000. 'Personality and job performance: the big five revisited', Journal of Applied Psychology, 85 (6): 869-879.

John, O.P, Naumann, L.P. \& Soto, C.J. (2008). Paradigm Shift to the integrative big five trait taxonomy: History, measurement and conceptual issues. In John, O.P., Robins, R.W. \& Pervin, L.A. (Eds.) Handbook of personality: theory and research. New York, USA: Guildford Press.

John, O.P. \& Srivastava, S. 1999. The big-five trait taxonomy: History, measurement, and theoretical perspectives. In Pervin, L. \& John, O.P. (Eds.) Handbook of personality: Theory and research. $2^{\text {nd }}$ Edition. New York, USA: Guilford.

Judge, T.A. \& Erez, A. 2007. 'Interaction and intersection: the constellation of emotional stability and extraversion in predicting Performance:, Personnel Psychology, 60(no issue): $573-596$
Judge, T.A., Thoresen, C.J., Bono, J.E. \& Patton, G.K. 2001. "The job satisfaction- job performance relationship; a qualitative and quantitative review', Psychological Bulletin, 127(3): 376-407.

Kjellerup, N. 2001. Personal view of the coming call centre boom in South Africa [Online]. URL: http://callcentres.comau/South_Africa_Call_Centre_Boom.. htm.

Lamont, L.M. \& Lundstrom, W.J. 1977. 'Tdentifying successful industrial salesmen by personality and personal characteristics', Joumal of Marketing Research, 14(4): 517529.

Liao, H. \& Chuang, A. 2004. 'Multilevel investigation of factors influencing employee service performance and customer outcomes', Academy of Management Journal, 47(1): 41-58.

Lucas, R.E., Diener, E., Grob, A., Suh, E.M. \& Shao, L. 2000. 'Cross cultural evidence for the fundamental features of extraversion', Journal of personality and Social Psychology, 79(3): 452- 468.

Malhotra, N.K. 2010. Marketing research: an applied orientation. $6^{\text {th }}$ Edition. New Jersey, USA: Pearson

Malhotra, N. \& Mukherjee, A. 2004. 'The relative influence of organisational commitment and job satisfaction on service quality of customer contact employees in banking call centres', Journal of Service Marketing, 18(3): 162-174.

Mechinda, P. \& Patterson, P.G. 2011. 'The impact of service climate and service provider personality on employees" customer-orientated behaviour in a high-contact setting," Journal of Services Marketing, 25(2):101-113.

McCrae, R. R. \& Costa, P.T. 2003. Personality in adulthood: a five-factor theory perspective. $2^{\text {nd }}$ Edition. New York: Guilford.

Mount, M.K., Barrick, M.R. \& Stewart, G.L. 1998. 'Fivefactor model of personality and performance in jobs involving interpersonal interactions', Human Performance, 11(1): $145-65$.

Nel, H. \& De Villiers, W.S. 2004. 'The relationship between emotional intelligence and job performance in a call centre environment', SA Journal of Industrial Psychology, 30(3): $75-81$.

Oschrin, E. 1918. 'Vocational tests for retail saleswomen', Journal of Applied Psychology, 2(2): 148-55.

Pervin, L.A., Cervone, D. \& John, O.P. 2005. Personality: Theory and research. $9^{\text {th }}$ Edition. New Jersey, USA: John Wiley \& Sons

Petrie, A. 2004. 'South Africa topples India in offshore call centre poll', Precision Marketing, 17(7):9-9. 
Price, J.L. 1995. 'A role of demographic variables in the study of absenteeism and turnover', International Journal of Career Management, 7(5): 26-32.

Rose, E., \& Wright, G. 2005. 'Satisfaction and dimensions of control among call centre customer service representatives', The International Journal of Human Resource Management, 16 (1): 136-160.

Rotundo, M. \& Sackett, P.R. 2002. 'The relative importance of task, citizenship, and counterproductive performance to global ratings of job performance: a policy-capturing approach', Journal of Applied Psychology, 87(1):66-80.

Sawyerr, O.O., Srinivas, S. \& Wang, S. 2009. 'Call centre employee personality factors and service performance', Journal of Services Marketing, 23(5): 301-317.

Schmitt, D.P. \& Shackelford, T.K. 2008. 'Big five traits related to short-term mating: From personality to promiscuity across 46 nations', Evolutionary Psychology, 6(2): $246-282$

Sharma, A., Rich, G.A. \& Levy, M. 2004. 'Comment: starting to solve the method puzzle in salesperson self-report evaluations.', Journal of Personal Selling \& Sales Management, 4(2): 135-139.

Silver, L.S., Dweyer, S. \& Alford, B. 2006. 'Learning and performance goal orientation of salespeople revisited: the role of performance-approach and performance-avoidance orientations', Journal of Personal Selling \& Sales Management, 26(1): 27-38.

Singh, R. \& Koshy, A. 2010. 'Determinants of B2B salespersons' performance and effectiveness: a review and synthesis of literature', Journal of Business and Industrial Marketing, 25(7): 536-546.

Skyrme, P., Wilkinson, L., Abraham, J.D. \& Morrison, J.D. 2005. 'Using personality to predict outbound call centre job performance', Applied HRM Research, 10(2): 89-98.

Stewart, G.L. \& Carson, K.P. 1995. 'Personality dimensions and domains of service performance: a field investigation', Journal of Business and Psychology, 9(4): 365-378.

Stone, B. \& Whyman, J. 1992. Successful telemarketing: opportunities and techniques for increasing sales and profits. $2^{\text {nd }}$ Edition. Chicago, USA: NTC Business Books.

Sujan, H., Weitz, B.A. \& Kumar, N. 1994. 'Learning orientations, working smart, and effective selling', Journal of Marketing, 58(3):39-50.

Vinchur, A.J., Schippmann, J.S., Switzer, F.S. \& Roth, P.L. 1998. 'A meta-analytic review of predictors of job performance for salespeople,' Journal of Applied Psychology, 83(4): 586-597.
Wang, G. \& Netemeyer, R.G. 2004. 'Salesperson creative performance: conceptualization, measurement, and nomological validity', Journal of Business Research, 57(8):805-812.

Warr, P., Bartram, D. \& Martin, T. 2005. 'Personality and sales performance: situational variation and interaction between traits', International Journal of Selection and Assessment, 13(1): 87-91.

Winde, 2011. South Africa named among top three emerging destinations- boost for Western Cape call centre industry. [Online]. URL: http:/www.capegateway.gov.za/eng/pubs/news/2011/sep/22 9561

Witt, L.A. 2002. 'The interactive effects of extraversion and conscientiousness on performance', Journal of Management, 28(6): 835-851.

Witt, L.A. \& Ferris, G.R. 2003. 'Social skill as moderator of the conscientiousness-performance relationship: convergent results across four studies', Journal of Applied Psychology, 88(5): 809-821. 